\title{
Impact of Teaching Civic and Religious Values in the National Curriculum on improving Social Responsibility in Tanzania: The Analytical View
}

\author{
Hamdun Sulayman \\ Al-Maktoum College of Engineering and Technology-Tanzania
}

\begin{abstract}
The paper analyses teaching values embedded in religious curricula particularly Christianity and Islam in the national curriculum of Tanzania to examine their effectiveness in imparting social responsibility spirit among civil servants which are essential in addressing moral challenges facing the nation. The curricula teach the youth principles, ideas and beliefs as general guides to their behaviour, and as points of reference in life that contribute to the wellbeing of Tanzanian society at large. Also, the curricula entail values that are closely connected to personal integrity and identity as Tanzanians with the hope that these values would influence decisions they make as adults in future. However, the analysis exercise has divulged that teaching moral values effectively with lasting effect has been rarely done in our schools, and hence, empowering learners with religious values, and shaping their behavior to impact the wellbeing of the nation seem to have lost its meaning.
\end{abstract}

Key words: Bible Knowledge, Islamic Knowledge, Civic values, National curriculum, Social responsibility

\section{Introduction}

Civic and religious curricula are part of the national secondary education curriculum of Tanzania that comprises 14 subjects (Ministry of Education, 1995), and is guided by the existing policy for self-reliance. Tanzanian citizens are taught and asked to advocate for values of self reliance, and to practice values advocated by two world religions curricula namely, Islamic Knowledge and Bible Knowledge. These values embedded in the three curricula are taught directly forming part of the national curriculum. They cut across the curricula, but taught differently to impact on students' lives and to effect changes and take action to address immoral practices in Tanzanian society. This paper is an endeavour to remind Tanzanians, particularly political leaders and those who are in the field of education about our lost values and our mission as a self-reliant nation to effective teaching positive values in order to restore our respectful position among the nations. The political leadership vision after independence was that the new form of education must change the mindset of teachers, students and all people to start thinking of a new self-dependent nation, and for that, everyone in society had to act accordingly (Sulayman 2007). The new national curriculum aimed at preparing young people to live in, and serve society, and to transmit the knowledge, skills, values and attitudes of society to Tanzanian people (Legum \& Mmari, 1995). The national aspiration, as articulated by Pendaeli (1983:40), was to produce individuals who were not only well educated, but also disciplined, self-reliant, had a nation building spirit, and advocated for the state values of unity, equality and justice in society.

\section{Rationale for the Paper}

Citizenship values and religious beliefs being the most determinants of a civilized nation, are taught in Tanzania national curriculum to establish a foundation in values that guides youth whilst still in school and their life in future as adults, civil servants and leaders. With this noble aim in mind curriculum developers have included citizenship values and religious beliefs in the national curriculum of colonial Tanganyika and the independent Tanzania. However, it is noted that this spirit has almost died in classroom teaching today (Sulayman, 2007). The President, officials and politicians, with the help of educationists and mass education media, succeeded in the 1960s and early 1970s in carrying the package of state values that currently, seem to have departed with their founder, Mwalimu Nyerere. The media has been reporting daily immoral practices and moral crisis that are afflicting the country ranging from petit practices such as vandalism and drug abuse to striking behaviour such as dishonest, embezzlement of public funds, laziness and corruption. Such practices have been a block stone that hinders development of the nation. This status quo of the nation necessitates more 
efforts to be employed by the political authority to restore our lost glory by laying a foundation for improving positive values teaching in our schools through empowering teachers to do so Fetterman (1999, 2001). If Mwalimu Nyerere succeeded to fight corruption and advocated for 'Ujamaa' African socialism values through the media and education, the author believes that their glory can be restored today by empowering teachers to teach moral values effectively.

\section{Historical Background of Teaching Moral Values in Tanzania}

There was a strong political will by the new government led by Mwalimu Nyerere in the 1960s and early in 1970s to restore African-centric positive values to all citizens through education (Sulayman, 2007). Following this move, there was strong speculation that the new leadership could make a difference through the Arusha Declaration. Mwalimu made it clear that positive values embedded in the Arusha Declaration, the principles and spirit of self-reliance should guide all activities and subjects taught in schools (Nyerere, 1967: 14). Following this political will, values and principles of self-reliance were memorized by all students in the national curriculum and emphasized at every political and non-political gathering. The author still memorize some phrases and slogans, known as the Party pledges which were taught to all pupils in the 1970s, like: ' Bribery is against justice, I will never receive or offer it', and 'I will tell the truth, be honest forever, and I will never be a hypocrite'. These phrases and others were compulsorily memorized by pupils and students throughout of the country. The cordial goal was to build a socialist and self-reliant nation that advocates for justice, equality, and respect for human dignity (Sulayman 1995, 2007) and ensures all form of injustice, intimidation, discrimination, corruption, oppression or favouritism are eradicated. Unlike the colonial education policy, the fundamental national goals and values in the Arusha Declaration, in which ESR was born, focused mainly on economic growth, and the provision of quality education, highlighting values of justice, equity, equality and self-reliance, away from begging. To make this clear and worthy, Mwalimu Nyerere changed the content of Civics curriculum to build a socialist state based on self-reliance values. He emphasises:

... we want to create a socialist society which is based on three principles: (1) equality and respect for human dignity; (2) sharing of the resources which are produced by our efforts; (3) work by everyone and exploitation by none. We have set out these ideas clearly in the National Ethic; and in the Arusha Declaration. (Nyerere, 1968:6).

Mwalimu Nyerere wanted a curriculum that delivered civic values and life skills. He also wanted a school to be a training centre for the young generation, a centre for learning the African values of living together, respect for human dignity, and learning different skills that will make people more independent and self-reliant.

\section{Analysis of Subjects Teaching Values in the National Curriculum}

Three curricula in the national curriculum of Tanzania, namely Civics, Islamic Knowledge [IK], and Bible Knowledge $[\mathrm{BK}]$ are reviewed and analyzed in this paper. The content of these national curricula are analyzed to indicate the specific values taught in schools and assessed as the foundation that future leaders may draw upon if and when they get into positions of power, to improve social responsibility in the country. Eight values are taught across all three curricula as displayed in Table 1below.

TABLE I: Values cutting across Civics, IK and BK curricula

\begin{tabular}{|lr|ll|}
\hline Values $\quad$ Cutting & $\sim$ equality & $\sim$ tolerance \\
Across all $\quad 3$ & $\sim$ justice & $\sim$ co-existence \\
Curricula: Civics, IK & $\sim$ respect for human dignity & $\sim$ truthfulness \\
and BK & $\sim$ fighting disease including HIV/AIDS & $\sim$ work \\
\hline
\end{tabular}

Values cutting across the 3 curricula discussed in this paper contribute to the laying of a values foundation. For example, 'co-existence' value in all three curricula refers to good relationship between different tribes, religious sects and ethnic groups in Tanzania and to being truthful in dealing with all people. The value in both religious curricula is given a religious flavour from the verses quoted in the curricula from the Qur-an and the Bible. A seventh values that cuts across the three curricula is 'fighting diseases including HIV/AIDS' which, in Civics, refers to the cultivation of a spirit of volunteering in civil awareness campaignsand taking preventative measures, including the use of condoms. IK and BK curricula do not, however, agree on the use of condoms; instead, they emphasise the core cause of the disease, which is stated in their curricula as moral decay and people engaging in adultery or sexual relationship outside the marriage. Informed by these assumptions, they advocate 
for abstinence, and spiritual educative campaigns to fight the disease. Related to this is 'participation in the fight against HIV/AIDS and STDs, and anti-communicable diseases campaigns'. The aim being to train students and all people in techniques with which to fight the three enemies cited by Mwalimu Nyerere as the big enemies undermining prosperity, self-reliance and ujamaa values, namely "ignorance, diseases, and poverty" (Nyerere, 1986:5).

In addition, Civics curriculum teaches secular values as enshrined in the Constitution of Tanzania, while IK and BK teach religious values lived by Tanzanian peoples as enshrined in the holy books of Islam, the Qur-an, and of Christianity, the Bible. What counts in teaching positive values is teacher's efforts to transform learner's mind and the inner-self of the learner to receive, acknowledge and take action to address immoral practices in the community, The major task of the school management is assisting teachers to sustain good practices in teaching values to impact the nation. This corresponds with Mwalimu Nyerere's desire that his ujamaa values be taught in Civics, and let Civics values go far beyond the school buildings to have an echo in society.

\subsection{Moral values taught in Civics curriculum}

The major concern of the content of Civics is imparting 'self-reliance' values, teaching people to be selfsufficient, just and not corrupt, teaching values of unity, identity and equality, and social values of fraternity, tolerance and hard working. Values taught in Civics as summarised in Table 2, aim to reflect the spirit of social transformation in Tanzania. Central to this transformation is a shift in the mindset of Tanzanians from dependency and euro-centric thinking to the self-reliance of individual citizens and Afro-centric thinking in a country where its people strive to provide for themselves and their families. Key to 16 values in this curriculum is independence, not domination, and 'Ujamaa' or self-reliance, not dependence. These values reflect those in the Civics secondary curricula of Forms 1-4 in the national curriculum as taught in Tanzanian schools.

TABLE II: Specific Values in Civics curriculum

\begin{tabular}{|c|c|c|c|}
\hline \multicolumn{4}{|c|}{ Overarching values specific to Civics Curricula [Form 1-4] } \\
\hline $\begin{array}{l}\text { National } \\
\text { ideology }\end{array}$ & $\begin{array}{l}\text { Inter- } \\
\text { relationships }\end{array}$ & National need & $\begin{array}{l}\text { Unity local \& } \\
\text { internationally }\end{array}$ \\
\hline $\begin{array}{l}\sim \text { self- } \\
\text { reliance }\end{array}$ & $\begin{array}{l}\sim \text { love and } \\
\text { fraternity }\end{array}$ & $\begin{array}{l}\sim \text { obedience to the law and authority } \\
\sim \text { fighting corruption } \\
\sim \text { patriotism } \\
\sim \text { good governance } \\
\sim \text { preservation of culture and environment }\end{array}$ & $\sim$ unity \\
\hline
\end{tabular}

Table 2 above lists 8 overarching values specific to Civics curriculum and are grouped into four groups for the sake of presentation. There are other 8 values taught in Civics shown in Table 1 under the values that cut across the 3 curricula.

\subsection{Moral values taught in Islamic Knowledge [IK] Curriculum}

Moving from the secular to the spiritual, central to the IK curriculum is a belief in the Oneness of Allah and remembering His existence at all times. Document analysis of IK curriculum revealed 19 overarching positive values taught in IK as listed in Table 3 below. These are the values related to believing in Oneness of God and service to humanity, social and political justice, equity and equality in community. The curriculum design that underpins IK being 'content-based', the ultimate goal of it is to inculcate Islamic values and call all people to the overarching values of Oneness of God the Almighty [Allah]. This is attained when its content is transferred into the learners' minds. The major focus of Islamic curricula is the inculcation of Islamic values and the liberation of students' mind from one-sided thinking of material life on earth to thinking of eternal life where everybody will be accountable for his/her own deeds. This motivates students as well as other people to be good citizens, do justice and avoid corruption or misbehaving, fearing the judgement in the Hereafter. Also, the objectives of IK are not far from the social values of unity, identity and equality, fraternity, tolerance and a hard working spirit as embedded in Civics. 
TABLE III: Values in Islamic Knowledge curriculum

\begin{tabular}{|c|c|c|c|}
\hline \multicolumn{4}{|c|}{ Overarching values specific to Islamic Knowledge [Form 1-4] } \\
\hline Relationship with Allah & $\begin{array}{l}\text { Inter- } \\
\text { relationships }\end{array}$ & National need & $\begin{array}{l}\text { Unity local and } \\
\text { global }\end{array}$ \\
\hline $\begin{array}{l}\text { believing in Allah and } \\
\text { remembering His existence all time } \\
\sim \text { self-righteousness } \\
\sim \text { performing prayers } \\
\sim \text { loving Islam } \\
\sim \text { obedience to Allah, the law and } \\
\text { authority }\end{array}$ & $\begin{array}{lr}\sim \text { kindness } & \text { and } \\
\text { compassion } & \\
\sim \text { modesty } & \text { in } \\
\text { dressing } & \text { and } \\
\text { everything } & \\
\sim \text { advocacy } & \text { for } \\
\text { good } & \end{array}$ & $\begin{array}{l}\sim \text { good governance } \\
\sim \text { jihad to fight } \\
\text { corruption and injustice }\end{array}$ & $\begin{array}{l}\text { Islamic } \\
\text { brotherhood } \\
\text { and solidarity }\end{array}$ \\
\hline
\end{tabular}

Table 3 above lists the values in the IK curricula. All eleven values are specific to the IK curriculum, in addition to other 8 values that cut across three curricula as displayed in Table 1, each adding to the foundation in values laid in this IK curriculum.

It is important to note that Islamic Knowledge curriculum emphasizes living by example by putting Islamic faith, teachings and values in action and advocating for them to maintain justice, equality and peace in society. This is also emphasised by Al-Hilali and Khan (1996:283-284) while interpreting three verses from the Holy Quran (Chapter 6, Verses 151-153) which advocate for Islamic values in society. They assert that twelve values are emphasized in these verses: keeping a monotheistic faith by worshiping the only one God, paying respect and being obedient to parents, not killing children because of poverty but believing that Allah provides sustenance through hard work, and avoiding all avenues that lead to illegal sex and shameful practices. Other values are prevalence of justice in society, avoiding brutality and uncivilized deeds like killing innocent people, and seeking knowledge to understand Allah's commandments. The context above also emphasizes the values of being honest and trustworthy, especially when an orphan's property is kept in one's custody, not only to look after it but also to make it grow through investment means until the orphan attains the age of full strength. Other values are being just in buying and selling, and telling the truth, even to oneself.

\subsubsection{Development of Islamic Knowledge curricula Forms 1-4}

Unlike Civics, IK is an optional subject chosen mainly by Muslim students and is the optional subject choice of approximately $35 \%$ of the school population. IK, its official name, is used to formally teach Islamic values in Tanzanian state schools but the length of the curriculum differs from grade to grade: Forms 1, 2 and 3, contain about 200 pages each and Form 4 about 300 pages. The new IK curriculum was developed in 1996 by the Revolutionary Government of Zanzibar [SMZ], in collaboration with the Supreme Muslim Council of Tanzania [BAKWATA] under supervision of the National Examination Council of Tanzania [NECTA], and approved by the latter in the same year. Currently the IK curriculum is offered at almost all the schools in the country under the title of 'Religion' subject, depending on the availability of Muslim teachers, from pre-primary to secondary schools.

\subsection{Moral values taught in Bible Knowledge [BK] Curriculum}

The positive values taught in BK to Christian students are those related to prayers, loving God [God Father, Gog the Son, God the Holy Spirit], and the entire humanity, and community service. The curriculum design that underpins BK is 'content-based' and the ultimate goal is to inculcate values of love and peace that are attained when the content is transferred into learners' mind. The major concern of BK as a subject is to teach people to be self-controlled and not to be arrogant, inculcating values of unity, fraternity and equality, tolerance, and a hard working spirit for economic development of the country as shown in Table 4 below. It is emphasized in the BK curriculum (CCT and TEC, 1998) that the Church must be concerned with the whole of man's life as the 'Declaration on Christian Education; Vatican II' document of 1966 directives display. The ten commandments of God are summarised in the BK curriculum too. 
TABLE IV: Values in Bible Knowledge curriculum

\begin{tabular}{|l|l|l|}
\hline \multicolumn{2}{|c|}{ Overarching values specific to Bible Knowledge BK curriculum[Form 1-4] } \\
\hline Relationship with God & Inter-relationships & National need \\
\hline$\sim$ love of God & $\sim$ love all people & $\sim$ patriotism \\
$\sim$ believing in 'Trinity' & $\sim$ kindness and compassion & $\sim$ fighting corruption \\
$\sim$ self-righteousness & $\sim$ serving humanity & \\
$\sim$ performing prayers & & \\
$\sim$ self-restraint & & \\
$\sim$ obedience to God and authority & & \\
\hline
\end{tabular}

As the case in IK, specific values in the BK curriculum fall into three groups, by virtue of similarity, as displayed in Table 4 above. The review of the BK curriculum indicates that the foremost values in the Bible Knowledge curriculum apart from the shared 8 values are a call for love for God and entire humanity, and offering help and services to people.

\subsubsection{Development of Bible Knowledge curricula Forms 1-4}

Like IK, BK is an optional subject chosen mainly by Christian students and represents about $50 \%$ of optional subject choices. BK is the official name of the curriculum formally teaching Christian values in Tanzanian state schools. The curricula for different Forms vary in length, from 64 pages in Form 1, to 62 pages in Form 2, and 30 and 32 pages in Forms 3 and 4 respectively (CCT and TEC, 1998). A new BK curriculum was developed in 1998 by the Christian Council of Tanzania [CCT] in collaboration with the Tanzania Episcopal Council [TEC] under supervision of the National Examination Council of Tanzania [NECTA]. It was first used in 1998 but has not yet been reviewed

\subsection{Teaching methods in the three curricula}

This section answers the question on 'How' values are taught in the three curricula; Civics, IK and BK, to lay a foundation in values for students to act properly and resist corruption, two methods and about five techniques seem to be used predominantly by teachers as captured in the three curricula.

In all three positive values curricula in the national curriculum of Tanzania, teachers arguably use whole class teaching methods with two variations: lecturing, which emphasises transmission of large amounts of information about values with little classroom interaction; and secondly a pedagogy referred to in these curricula [IK and BK particularly] as 'parables' where teaching the class takes place with reference to the exemplary lives of people(SMZ and BAKWATA, 1996:2; CCT and TEC 1998). This is the predominant classroom pedagogy for teaching values in these curricula.

In general, teachers in the three curricula use two methods and five techniques whilst teaching positive values. The methods used are, 'whole class-instruction methods', ranging between lecturing and parable-telling, in which the teacher is everything, and rarely, 'participatory and discussion methods' in large groups to allow open discussion, free and flexible communication between the teacher and students. The techniques used by teachers of positive values include the 'use of continuous assessment techniques' to gauge students' understanding of positive values and to assess their delivery of positive values, 'group discussion', in large groups, to learn through doing, 'parable-telling', 'lecturing and preaching techniques', and 'recitation and memorization of the Holy Books'.

\section{Challenges in Teaching Values and Recommended Solutions}

Four challenges in teaching positive values in the national curriculum of Tanzania have been identified in this paper. Solutions for each challenge have been also suggested and recommended for immediate and effective action.

\subsection{Integration of Moral values in Tanzanian national curriculum}

The foremost challenge is that moral values embedded in the religion and Civics subject are seen as a standalone programme in the national curriculum. It is suggested here that moral values not to be taught as a subject in the traditional sense, it is rather, be integrated in all school subjects in what is called a 'correlation design curriculum' in which ssubjects are related to one another but each subject maintains its identify. Doing so, will help to include a variety of activities embracing enrichment, personal development, community service, 
recreation and nurturing as learning within and from different angles of the existing curricula. In this way, moral values will be integrated in whole school policy as well as in other academic disciplines. This will help to impart confidence to students and build their self-determination to resist immoral practices when encountered in life. The values suggested here to be integrated in all 14 subjects are those shown in Table 1 as reflected in the Civics, IK and BK national secondary education curricula from Form One up to Form Four

\subsection{Making safeguarding subjects in the national curriculum optional}

The second challenge which is related to the previous challenge is making religion an optional subject. Religious subjects are the core in bringing tranquillity and peace in society. IK and BK being optional subjects in the current national curriculum of Tanzania are taken only by students who elect to study them for a variety of reasons; one being because they strengthen their faith, another as a fill-in. Hence, the subjects are not as influential as Civics as far as laying a foundation in values for students is concerned. However, the three curricula collectively provide choices to students when making decisions in their present and future life. Statistics from a field survey done in 2005 (Sulayman, 2007) shows that the two optional subjects, IK and BK are taken by about $35 \%$ and $45 \%$ of students respectively, suggesting that only $80 \%$ of all students are learning additional values on top of secular values, and they could, therefore, make choices based on their spirituality. This suggests too, that the religiously based values curricula are likely to be less influential in decisions students make than secular values taught in Civics. A quirk of education in Tanzania is that its being a secular state it has no desire to further any one religion and hence neither appoints nor remunerates IK or BK teachers, only Civics teachers. The law states categorically that religious institutions not only have to provide IK and/or BK teachers but also have to train and pay them to teach these curricula in state schools. IK and BK do not attract as many students as Civics, because the former are not compulsory subjects whilst the later is. Also, suggestion is made here that learning religious subjects must be compulsory in all schools and be under the supervision of the Ministry.

\subsection{Time allocated for Civics and Religion subjects a week}

Related to the third challenge is the time allocated for the 3 curricula of 90 minutes a week. This time is not sufficient for effective teaching of values. Two periods of 90 minutes a week have been allocated for each subject in all three curricula. Surprisingly, the number of periods allocated for Civics a week differs from other compulsory subjects such as Mathematics and English 6 periods each, and Kiswahili 4 periods. The curriculum developers have to allocate more time for the three curricula, because they have equal importance with Mathematics and English!

\subsection{Teaching methods used in teaching Religion and Civics subjects}

The fifth challenge is the methods and strategies used in teaching religious and civics subjects in our schools. Two methods in the whole-class instruction setting are used in teaching values across the three curricula. The 'whole-class instruction' method, or lecturing, and the use of large group discussions led by the teacher seems to be predominantly used in religious curricula. In the whole classroom teaching setting, the teacher is everything; it is s/he who initiates classroom activities, and values to be discussed. Also, as instructed in the IK and BK curricula, most values are predominantly taught through lecturing, preaching, and parabletelling techniques in a whole-classroom teaching set-up, perhaps because parables telling, which is an overriding feature in the Holy books, helps to develop man's constructive thinking skills. These traditional teaching methods in which the teacher is everything seem to be less effective in delivering positive values so as to guide students in the choices they make against immoral practices. They merely help them to memorize the facts for the tests. For this reason, the argument is made in this study for rethinking the way of teaching values in three curricula to impact on students' lives and to provide them with alternative choices in decisions they make to impact improvement of social responsibility in society.

\section{Recommendations}

Four general recommendations have been made in this paper. Most of them are directed to the Ministry of Education in Tanzania, urging them to act on the recommendations so as to sustain values teaching in Tanzanian schools in a way that it makes an impact on improving social responsibility in the society.

- The Ministry of Education must employ religious teachers because religion as a teaching subject is now being taught in colleges of education at diploma and degree levels. This will make teachers feel that the Ministry values their role in teaching positive values. 
- To improve and sustain successful delivery, we must implement in-service training scheme to keep teachers spirit higher. For this, in-service training should be organized for building teachers' capacity and empowerment evaluation approach can be used for this end. The findings of the study overwhelmingly suggest a need for workshops and training in the pedagogy and use of materials for Civics and religion teachers to help them plan and execute the teaching of values in such a way that it will have a lasting effect as intended in the national curriculum.

- Making an adequate package of positive values part of all subjects taught in school, because educating a child involves developing his/her mental, emotional, spiritual, religious and physical fitness. That is to say, inculcating positive values in our children should be made the official responsibility of all teachers and should not be left to Civics and religious teachers or discipline masters alone. Our language textbooks should have more lessons emphasizing the importance of moral values and their practical benefits to us in our daily lives. In schools and colleges, values education could be made a compulsory subject for all students. Positive values courses could be introduced at university and college levels as part of orientation and/ communication skills courses since they would help students deal with other people and facilitate the development of better inter-personal and communication skills, which are assets for everyone in a service-oriented profession.

- Airing values programmes in the media, especially in TV programmes, to seek public opinions and solutions on moral issues and debates on moral values. At the same time, proper censorship of everything broadcasted or aired on TV is strongly recommended. Also, all journals and magazines such as 'Kasheshe', 'Ijumaa' and alike that display and encourage immoral practices in society should be banned.

\section{Conclusion}

The analysis of three curricula has revealed that, there are about 231 specific values in the national curriculum organized under the overarching values of 'self-reliance' in Civics curriculum, 'believing in Oneness of God' in the IK curriculum, and 'loving God and all people as oneself' in the BK curriculum, provide students with moral precepts to guide their lives, including their role in improving social responsibility in the country. These ideologies and beliefs aim to establish and provide students with secular and spiritual choices and tools for recognizing the right from the wrong, and to be fair by doing justice, and maintaining as well as sustaining the peace and love of everybody in society. These values if taught effectively and used as the guide, may provide to students ability to make positive choices towards building a self-dependent nation that can be respected among the nations. Until we empower teachers to drive the effective change of the youth whilst still at school for them to apply positive values as adults to improve social responsibility in their workplaces, the big challenge will remain how to teach moral values with lasting effect.

\section{References}

[1] Al-Hilali Muhammad Taqi-ud-Din \& Khan Muhammad Muhsin, Interpretation of the Meaning of The Noble Qur'an in the English Language: Summarized in one volume. Riyadh: Dar-us- Salaam Publishers and Distributors, 1996.

[2] C C T \& T E C Haya ndiyo Maisha ya Kikristo. Masomo ya dini kwa Shule za Sekondari Kidato cha 1 - 4. Mwanza Tanzania: Inland Press 20M.. 1998.

[3] Fetterman D M, "Reflections on Empowerment Evaluation: Learning from Experience," Canadian Evaluation Society. Canadian Journal of Program Evaluation, Special Issue, pp. 5 - 37, 1999.

[4] Fetterman D M, Foundations of Empowerment Evaluation. California: Sage Publications Inc. Thousand Oaks, 2001.

[5] Komba W L M. Citizenship Education in Post-Socialist Plural Tanzania: Teachers' Perception of Their Role. Papers in Education and Development, Dar es Salaam: University of Dares Salaam, 1999.

[6] Legum Colin and Mmari Geoffrey. MWALIMU: The influence of Nyerere. The executive Committee of the Britain Tanzania Society, UK Chapter, 1995.

[7] Ministry of Education Education and Training. Dar es Salaam: Ministry of Education, 1995.

[8] Ministry of Education. Civics Syllabus For Sec. Schools: Form 1-4, Dar es Salaam: Ministry of Education 1997.

[9] Mlekwa Victor, Adult Education and Political Socialization: The Dynamics of Their Interaction in the Context of Tanzania. Papers in Education and Development 13, Dar es Salaam: University of Dar es Salaam, 1989.

[10] Nyerere J K, Freedom and Unity. Dar Es salaam: Oxford University Press, 1967. 
[11] Nyerere J K, Freedom and Socialism. Dar es Salaam: Oxford,1968.

[12] Pendael, in Legum Colin \& Mmari Geoffrey, MWALIMU: The influence of Nyerere. The executive Committee of the Britain, Tanzania Society, UK Chapter, 1995.

[13] SMZ and BAKWATA Muhtasari wa Elimu ya Dini ya Kiislamu. Shule za Sekondary Kidato cha I - IV. Tanzania: Educational Panel, 1996.

[14] Sulayman H I. Factors Contributing to Crisis in Students' Moral Character and Ethical Values in Sec. Schools of Tanzania, Unpublished M.A. Dissertation. Dar es Salaam : University of Dar es Salaam, 1995.

[15] Sulayman H I. Building Values in 3 Schools of Tanzania: A Participatory, Colaboratory and Empowerment Evaluation Approach. PhD Thesis, WITS. Johnnesburg, 2007. 